Check for updates

Montreal

Cite this as: BMJ2020;371:m4781 http://dx.doi.org/10.1136/bmj.m4781 Published: 10 December 2020

\section{Covid-19: Fired Florida statistician says police raid aimed to identify her government contacts}

\author{
Owen Dyer
}

A former covid-19 data analyst for the state of Florida, who was fired after claiming that her superiors were hiding cases and deaths and went on to create her own acclaimed national covid dashboard, ${ }^{1}$ said that a raid by armed police on her home was an effort by the governor's office to find the names of her government contacts, in an ongoing "purge" of the health department.

“I don't think they're after me,” Rebekah Jones told CNN after the 7 December raid. "On my phone is every communication I've ever had with someone who works for the state who has come to me in confidence and told me something that could get them fired.

"This is just a very thinly veiled attempt by the governor to intimidate scientists and get back at me while trying to get to my sources."

Video of the raid taken from inside the home shows Jones opening the door to state police officers who enter brandishing guns. ${ }^{2}$ After being told that her husband and children are upstairs, one policeman brusquely demands that they come down, while pointing his pistol up the stairwell.

A state police spokesman later said that Jones had kept officers with a search warrant waiting for 20 minutes outside her door.

Her Tallahassee home was raided, police said, after an IP address linked to it was found to be the source of a 10 November message sent to 1750 members of the state emergency response team, which was deemed a case of unauthorised hacking.

"It's time to speak up before another 17 ooo people are dead," the message said. "You know this is wrong. You don't have to be part of this. Be a hero. Speak out before it's too late."

Jones denied sending the message, noting that the message undercounted Florida's deaths by 430 . "I would never round down 430 deaths," she said.

The raid drew widespread condemnation from statisticians, scientists, and lawmakers and prompted the resignation of one state government attorney, who wrote after seeing the search warrant affidavit that "I no longer wish to serve the current government of Florida in any capacity."

The firing of Jones in May for what governor Ron DeSantis called "insubordination" focused attention on Florida's secretive approach to covid data. She later filed a whistleblower complaint alleging that she had refused demands to falsify data, including an order to present the state's $18 \%$ test positivity rate as being under $10 \%$.

An investigation by the South Florida Sun Sentinel found that the governor's office and health department had engaged in a "pattern of spin and concealment that misled the public on the gravest health threat the state has ever faced." 3

Until it was threatened with legal action, the state refused to report numbers of covid-19 cases in nursing homes, prisons, hospitals, and schools. In September the Sun Sentinel found that health department employees had been told to stop posting social media messages about covid-19 until after the election.

Instead of seeking advice from Florida's many eminent epidemiologists and infectious disease specialists, DeSantis has leaned on the advice of outsiders who agree with his position, such as Trump covid adviser Scott Atlas. Florida hired a sports blogger and mask critic from Ohio to be its new covid-19 data analyst. DeSantis has barred mayors from enforcing mandatory mask wearing.

DeSantis's spokesman denied that the governor had foreknowledge of the police raid. "The governor was not aware of the investigation nor will he offer his opinion on what information should or should not be used in any criminal prosecution," said Fred Piccolo in a statement.

Piccolo has himself been a regular source of misinformation on covid-19, the Sun Sentinel found, understating daily death counts, questioning the benefits of masks, and tweeting that the virus was "less deadly than the flu."

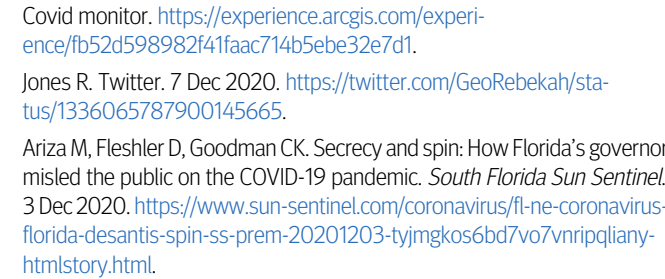

Ariza M, Fleshler D, Goodman CK. Secrecy and spin: How Florida's governo misled the public on the COVID-19 pandemic. South Florida Sun Sentinel. 3 Dec 2020. https://www.sun-sentinel.com/coronavirus/fl-ne-coronavirusflorida-desantis-spin-ss-prem-20201203-tyjmgkos6bd7vo7vnripqlianyhtmlstory.html. 